\title{
Weed Control in Strawberry Provided by Shank- and Drip-applied Methyl Bromide Alternative Fumigants
}

\author{
S.A. Fennimore and M.J. Haar \\ University of California-Davis, Department of Vegetable Crops, 1636 East \\ Alisal Street, Salinas, CA 93905
}

\begin{abstract}
H.A. Ajwa ${ }^{1}$
U.S. Department of Agriculture, Agricultural Research Service, Water Management Research Laboratory, 9611 S. Riverbend, Parlier, CA 93648
\end{abstract}

Additional index words. 1,3-D, chloropicrin, drip fumigation, metam sodium, methyl bromide, Fragaria $\times$ ananassa, weed seed viability

\begin{abstract}
The loss of methyl bromide (MB) as a soil fumigant has created the need for new weed management systems for crops such as strawberry (Fragaria $\times$ ananassa Duchesne). Potential alternative chemicals to replace methyl bromide fumigation include 1,3-D, chloropicrin (CP), and metam sodium. Application of emulsified formulations of these fumigants through the drip irrigation system is being tested as an alternative to the standard shank injection method of fumigant application in strawberry production. The goal of this research was to evaluate the weed control efficacy of alternative fumigants applied through the drip irrigation system and by shank injection. The fumigant 1,3-D in a mixture with CP was drip-applied as InLine (60\% 1,3-D plus 32\% CP) at 236 and 393 $\mathrm{L} \cdot \mathrm{ha}^{-1}$ or shank injected as Telone C35 $\left(62 \%\right.$ 1,3-D plus 35\% CP) at $374 \mathrm{~L} \cdot \mathrm{ha}^{-1}$. Chloropicrin (CP EC, $95 \%)$ was drip-applied singly at 130 and $200 \mathrm{~L} \cdot \mathrm{ha}^{-1}$ or shank injected $(\mathrm{CP}$, $99 \%$ ) at $317 \mathrm{~kg} \cdot \mathrm{ha}^{-1}$. Vapam HL (metam sodium $42 \%$ ) was drip-applied singly at 420 and $700 \mathrm{~L} \cdot \mathrm{ha}^{-1}$. InLine was drip-applied at 236 and $393 \mathrm{~L} \cdot \mathrm{ha}^{-1}$, and then $6 \mathrm{~d}$ later followed by (fb) drip-applied Vapam HL at 420 and $700 \mathrm{~L} \cdot \mathrm{ha}^{-1}$, respectively. CP EC was drip-applied simultaneously with Vapam HL at 130 plus $420 \mathrm{~L} \cdot \mathrm{ha}^{-1}$ and as a sequential application at $200 \mathrm{fb} 420 \mathrm{~L} \cdot \mathrm{ha}^{-1}$, respectively. Results were compared to the commercial standard, MB : CP mixture (67:33) shank-applied at $425 \mathrm{~kg} \cdot \mathrm{ha}^{-1}$ and the untreated control. Chloropicrin EC at $200 \mathrm{~L} \cdot \mathrm{ha}^{-1}$ and InLine at 236 to $393 \mathrm{~L} \cdot \mathrm{ha}^{-1}$ each applied singly controlled weeds as well as MB : CP at $425 \mathrm{~kg} \cdot \mathrm{ha}^{-1}$. Application of these fumigants through the drip irrigation systems provided equal or better weed control than equivalent rates applied by shank injection. InLine and CP EC efficacy on little mallow (Malva parviflora L.) or prostrate knotweed (Polygonum aviculare $\mathrm{L}$.) seed buried at the center of the bed did not differ from MB : CP. However, the percentage of weed seed survival at the edge of the bed was often higher in the drip-applied treatments than in the shank-applied treatments, possibly due to the close proximity of the shank-injected fumigant to the edge of the bed. Vapam HL was generally less effective than MB : CP on the native weed population or on weed seed. The use of Vapam HL in combination with InLine or CP EC did not provide additional weed control benefit. Chemical names used: 1,3-dichloropropene (1,3-D); sodium N-methyldithiocarbamate (metam sodium); methyl bromide; trichloronitromethane (chloropicrin).
\end{abstract}

For the past 40 years, soil fumigation with methyl bromide (MB) has been the basis for pest management in California strawberry (Fragaria xananassa Duchesne) production (Wilhelm and Paulus, 1980). Application of $\mathrm{MB}$ in combination with chloropicrin (CP) has provided consistent cost-effective control of soilborne diseases, nematodes and weeds. Nearly all conventionally produced

Received for publication 21 Dec. 2001. Accepted for publication 8 May 2002. Mention of trade names or proprietary products is for the convenience of the reader only, and does not constitute endorsement or preferential treatment by USDA/ARS or the Univ. of California.

${ }^{1}$ To whom reprint requests should be addressed. Current address: Univ. of California-Davis, 1636 East Alisal St., Salinas, CA 93905. strawberries in California are grown in soil fumigated with a mixture of $\mathrm{MB}$ and $\mathrm{CP}$ (MB : CP). In the United States, soil fumigation consumes 35 million pounds of methyl bromide each year; $\approx 50 \%$ is used in California and $35 \%$ in Florida [U.S. Dept. of Agriculture (USDA), 2000]. Methyl bromide has been classified as an ozone-depleting substance, and under the provisions of the U.S. Clean Air Act and international treaty, MB use in the United States will be phased out by 2005 (USDA, 2000). Effective alternatives must be found to control soilborne diseases and weeds, otherwise the impact of the MB phaseout could cause severe economic distress for the strawberry industry (Carter, 2001).

Profitable strawberry production depends on effective weed management. Strawberries are extremely vulnerable to weed competition, and weeds can harbor pathogens and insects that are deleterious to the crop (Agamalian et al., 1994; Lange, 1985). Effective weed control in California strawberries has been accomplished through a combination of field selection, crop rotation, sanitation, hand weeding, mulching, preplant soil fumigation, and occasionally, herbicides (California Strawberry Commission, 1999). Common weeds of strawberry controlled by $360 \mathrm{~kg} \cdot \mathrm{ha}^{-1}$ of $2 \mathrm{MB}$ : $1 \mathrm{CP}$ include pigweeds (Amaranthus sp.), common lambsquarters (Chenopodium album L.), shepherd's-purse (Capsella bursa-pastoris L. Medik.), common purslane (Portulaca oleracea L.), common chickweed [Stellaria media (L.) Vill.], and hairy nightshade (Solanum sarrachoides Sendtner) (Wilhelm and Paulus, 1980). Serious weed pests in strawberry that are not controlled by this treatment are little mallow (Malva parviflora L.), California burclover (Medicago polymorpha L.), Indian sweetclover [Melilotus indica (L.) All.], redstem filaree [Erodium dircutarium (L.) L Herr. ex. Ait], and purple cudweed (Gnaphalium purpureum L.) (Agamalian et al., 1994; Wilhelm and Paulus, 1980). Both burclover and little mallow have hard seed coats that contribute toward their persistence in the soil seedbank (Makowski and Morrison, 1989; Porqueddu et al., 1996). The mechanisms by which burclover and little mallow resist MB : CP fumigation are unknown. However, it is likely that the hard seed coat either partially or fully prevents a lethal concentration of fumigant from penetrating the seed and killing the embryo (Egley, 1986). Weeds in strawberry fields not controlled by fumigants must be pulled by hand because plastic mulches preclude the use of mechanical tillage (Agamalian et al., 1994). If alternative fumigants do not provide weed control at levels previously provided by MB : CP fumigation, yield will be reduced and hand-weeding expense will increase.

Commercially available alternatives to $\mathrm{MB}$ are $\mathrm{CP}, 1,3-\mathrm{D}$, and metam sodium (Ajwa et al., 2001). Chloropicrin became a partner with MB in the late 1950s, when it was learned that the combination of both fumigants was very effective in controlling soilborne pathogens, insects, and weeds (Wilhelm, 1999; Wilhelm and Paulus, 1980). Although the efficacy of CP on soilborne pathogenic fungi is well documented (Wilhelm, 1999), limited information is available on its performance on weeds. The weed control spectrum of $\mathrm{CP}$ applied alone or 1,3-D plus CP in combination have not been well defined. Limited laboratory studies indicate that $\mathrm{CP}$ or $1,3-\mathrm{D}$ can provide adequate control of some weed species such as redroot pigweed (Amaranthus retroflexus L.) (Pieczarka and Warren, 1959, 1960). However, recent evidence indicates that shank injected $\mathrm{CP}$ and 1,3-D do not control other weeds such as nutsedge (Cyperus sp.), a species that MB does control (Locascio et al., 1997). Metam sodium itself is not active on weeds, but it quickly breaks down after application to methyl isothiocyanate (MITC), a compound active against weeds such as large crabgrass (Digitaria sanguinalis L. Scop.) (Teasdale and Taylorson, 1986), burning nettle (Urtica urens 
L.), common chickweed and pigweeds. MITC may also provide partial control of burclover and little mallow (Agamalian et al., 1994) and nutsedge (Locascio et al., 1997).

Alternative fumigants must provide economical control of nematodes, soil pathogens and weeds. Methyl bromide not only provides weed control, but control of nematodes and soil pathogens (Wilhelm and Paulus, 1980). Chloropicrin has a high level of activity against insects and many fungi, but is less active against nematodes than MB : CP(Duniway et al., 2001; Johnson and Feldmesser, 1987; Johnson et al., 1979; Wilhelm and Paulus, 1980). The activity of 1,3-D on nematodes and some insects is high, but activity against soil pathogens is less consistent (Noling and Becker, 1994). Metam sodium provides control of nematodes and soil borne pathogens (Johnson et al., 1979; McCarter et al., 1976).

A Univ. of California economic analysis projects that California strawberry industry revenues will decline by $15 \%$ from current levels after implementation of the MB phaseout (Carter, 2001). Therefore, it is essential that alternative fumigant treatments allow growers to remain economically viable. Estimated costs of alternative fumigants are $\$ 600$ per hectare for a $700 \mathrm{~L} \cdot \mathrm{ha}^{-1}$ metam sodium application, $\$ 1700$ per hectare for a $317 \mathrm{~kg} \cdot \mathrm{ha}^{-1}$ shank-applied CP treatment and $\approx \$ 3200$ per hectare for a $374 \mathrm{~L} \cdot \mathrm{ha}^{-1}$ shank-applied 1,3-D plus CP treatment (Rachael Goodhue, personal communication, Table 1). Compared to MB : CP fumigation costs at $\$ 4200 /$ ha, these alternative fumigant treatments are cheaper (Klonsky and De Moura, 2001).

Methyl bromide is typically applied to soil or raised soil beds by injection through hollow shanks that are pulled through the soil at a depth of 20 to $30 \mathrm{~cm}$. The soil is covered by plastic mulch film immediately after application. Although alternative soil fumigants such as $\mathrm{CP}$ or mixtures of 1,3-D and $\mathrm{CP}$ can be applied by shank injection (Locascio et al. 1997), their volatilization and distribution in soil may be limited by their lower vapor pressure and higher boiling point compared to MB (EXTOXNET - CP, 2001; EXTOXNET - MB 2001; Lakes Environmental Software, 2000). Fumigants such as TeloneC35 (Dow Agro Sciences, Redeck, N.C.) (62\% 1,3-D and $35 \% \mathrm{CP}$ ) or $\mathrm{CP}$ alone can be more effective when applied with water through the drip irrigation system than when applied by shank injection. Ajwa et al. (2001) proposed drip fumigation as an alternative method of fumigant application for drip-irrigated crops such as strawberries. Long-term research by Ajwa and Trout (2000) reported that soil beds drip fumigated with emulsifiable concentrate (EC) of TeloneC35 (InLine) at $393 \mathrm{~L} \cdot \mathrm{ha}^{-1}$ applied singly, produced strawberry yields equivalent to $67 \mathrm{MB}: 33 \mathrm{CP}$ shank fumigation at 425 $\mathrm{kg} \cdot \mathrm{ha}^{-1}$. Other advantages of drip fumigation over shank injection include a more uniform distribution of chemicals, reduced applicator exposure, and lower rates (Ajwa et al., 2002). Although application of available alternative fumigants through the drip irrigation system may be an option in irrigated crops such as
Table 1. Fumigant rate, application method, irrigation water volume, and cost estimates.

\begin{tabular}{|c|c|c|c|c|}
\hline Treatment & Rate/ha & $\begin{array}{c}\text { Application } \\
\text { method }\end{array}$ & $\begin{array}{c}\text { Irrigation } \\
\text { vol } \\
\left(\mathrm{L} \cdot \mathrm{m}^{-2}\right)\end{array}$ & $\begin{array}{c}\text { Cost } \\
\text { estimates } \\
(\$ / h a)^{z}\end{array}$ \\
\hline$\overline{\mathrm{MB}}: \mathrm{CP}$ & $425 \mathrm{~kg}$ & shank & --- & 2623 \\
\hline Telone C35 (62\% 1,3-D and $35 \%$ CP) & $374 \mathrm{~L}$ & shank & --- & 3212 \\
\hline CP $(99 \%)$ & $317 \mathrm{~kg}$ & shank & --- & 1673 \\
\hline InLine $(60 \%$ 1,3-D and $32 \% \mathrm{CP})$ & $236 \mathrm{~L}$ & drip & 43 & 1450 \\
\hline \multicolumn{5}{|l|}{ InLine followed by $(\mathrm{fb})^{\mathrm{y}}$} \\
\hline Vapam (metam sodium 42\%) & $236 \mathrm{fb} 420 \mathrm{~L}$ & drip & $43 \mathrm{fb} 26$ & 1802 \\
\hline InLine & $393 \mathrm{~L}$ & drip & $26,43,61$ & 2414 \\
\hline InLine fb Vapam & $393 \mathrm{fb} 700 \mathrm{~L}$ & drip & $61 \mathrm{fb} 26$ & 3001 \\
\hline CP EC $(95 \%)$ & $130 \mathrm{~L}$ & drip & 43 & 1134 \\
\hline CP EC $(95 \%)$ & $200 \mathrm{~L}$ & drip & 43 & 1745 \\
\hline $\mathrm{CP} \mathrm{EC}$ + Vapam & $130+420 \mathrm{~L}$ & drip & 43 & 1487 \\
\hline CP EC fb Vapam & $200 \mathrm{fb}^{\mathrm{y}} 420 \mathrm{~L}$ & drip & $43 \mathrm{fb} 26$ & 2097 \\
\hline Vapam & $420 \mathrm{~L}$ & drip & 43 & 352 \\
\hline Vapam & $700 \mathrm{~L}$ & drip & $26,43,61$ & 587 \\
\hline Untreated & 0 & --- & -- & --- \\
\hline
\end{tabular}

${ }^{2}$ Cost estimates based on a survey of commercial dealers in California. Application costs were not included.

$\mathrm{y}_{\mathrm{fb}}=$ followed by Vapam $6 \mathrm{~d}$ later. strawberry, little information is available regarding the weed control efficacy of this fumigation method. The first objective of this research was to evaluate the weed control efficacy of preplant drip fumigation with 1,3-D plus $\mathrm{CP}$ in mixture, $\mathrm{CP}$, and metam sodium. The second objective was to evaluate the effect of combining 1,3-D plus CP mixture or $\mathrm{CP}$ alone with a metam sodium treatment. The third objective was to compare the weed control efficacy at equal rates of drip-applied and shank-applied 1,3-D plus CP mixture.

\section{Materials and Methods}

Site description and treatment application. Field studies were conducted in Salinas and Watsonville, Calif., for two consecutive years, Sept. 1998 through July 1999 (1999 growing season) and Oct. 1999 through Aug. 2000 (2000 growing season). Both sites were located in a major strawberry production district on the central coast of California. Soil at both locations had not been fumigated for at least 10 years prior to initiation of this research. The soil at
Table 2. Effect of MB : CP and alternative fumigants on weed fresh weight. Total mean weed fresh weight $\mathrm{g} \cdot \mathrm{m}^{-2}$ of shank-applied MB : CP was compared to CP, Inline, Telone C35, or Vapam HL applied through the drip irrigation system or by shank injection at Salinas and Watsonville. The weed biomasses in the InLine and CP EC treatments with and without Vapam HL were contrasted to determine if sequential applications of Vapam HL improved weed control. Weed biomass in the InLine and Telone C35 treatments were also contrasted.

\begin{tabular}{|c|c|c|c|c|}
\hline Treatment & Rate/ha & $\begin{array}{l}\text { Application } \\
\text { method }\end{array}$ & $\begin{array}{c}\text { Salinas } \\
1999\end{array}$ & $\begin{array}{l}\text { Watsonville } \\
2000\end{array}$ \\
\hline & Contrast sin & ments vs. MB & $\begin{array}{l}-----\mathrm{g}^{-2} \\
\text { standard }\end{array}$ & ----- \\
\hline MB : CP standard & $425 \mathrm{~kg}$ & shank & 39.0 & 20.3 \\
\hline Telone C35 & $374 \mathrm{~L}$ & shank & $48.3(0.81)^{z}$ & $50.0(0.17)$ \\
\hline Inline & $236 \mathrm{~L}$ & drip & $25.5(0.98)$ & $14.9(0.80)$ \\
\hline Inline & $393 \mathrm{~L}^{y}$ & drip & $17.3(0.55)$ & $7.1(0.44)$ \\
\hline CP EC & $130 \mathrm{~L}$ & drip & $31.3(0.78)$ & $10.8(0.65)$ \\
\hline Vapam HL & $420 \mathrm{~L}$ & drip & $98.9(<0.01)$ & $15.6(0.82)$ \\
\hline Vapam HL & $700 \mathrm{~L}^{\mathrm{x}}$ & drip & $89.2(<0.01)$ & $4.8(0.40)$ \\
\hline Untreated & 0 & --- & $516.6(<0.01)$ & $186.7(<0.01)$ \\
\hline
\end{tabular}

Contrast fumigant applied alone vs. fumigant followed by $(f b)$ Vapam $H L$

$\begin{array}{lllll}\text { Inline } & 236 \mathrm{~L} & \text { drip } & 25.5 & 14.9\end{array}$

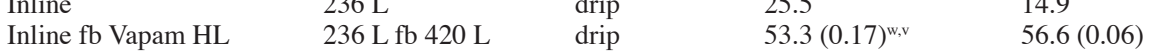

$\begin{array}{lllll}\text { Inline } & 393 \mathrm{~L}^{\mathrm{y}} & \text { drip } & 17.3 & 7.1\end{array}$

Inline fb Vapam HL $\quad 393 \mathrm{~L} \mathrm{fb} 700 \mathrm{~L} \quad$ drip $\quad 15.5(0.91)^{\mathrm{w}}$

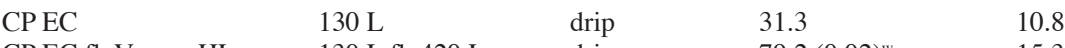

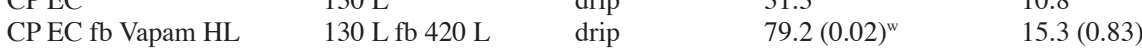

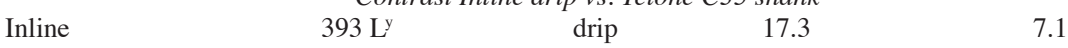

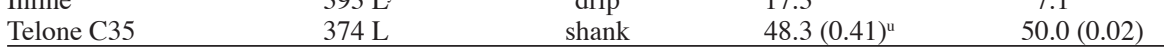

${ }^{2} \mathrm{P}$ value of single $\mathrm{df}$ contrasts comparing weed biomass weights with the $\mathrm{MB}: \mathrm{CP}$ standard.

${ }^{y}$ Average weed biomass of Inline at $393 \mathrm{~L} \cdot \mathrm{ha}^{-1}$ applied by drip irrigation in three application volumes: 26 , 43 , and $61 \mathrm{~L} \cdot \mathrm{m}^{-2}$.

${ }^{x}$ Average weed biomass of Vapam $\mathrm{HL}$ at $700 \mathrm{~L} \cdot \mathrm{ha}^{-1}$ applied by drip irrigation in three application volumes: 26,43 , and $61 \mathrm{~L} \cdot \mathrm{m}^{-2}$.

"Inline or CP EC were applied simultaneously in 1999.

${ }^{v} P$ value of single $\mathrm{df}$ contrasts comparing the weed biomass of Inline or CP EC treatments applied with a sequential application of Vapam HL were compared to Inline or CP applied without Vapam HL.

" $P$ value of single df contrasts comparing the weed biomass from the Inline drip-applied treatment to the Telone C35 shank-applied treatment. 
Salinas was classified as a Chualar sandy loam (fine-loamy, mixed, thermic, Typic Argixerolls) with a pH of 6.5 and organic matter content of $0.7 \%$. The soil in Watsonville was classified as an Elder sandy loam (coarse-loamy, mixed, thermic, Cumulic Haploxerolls) with a $\mathrm{pH}$ of 6.1 and organic matter content of $0.6 \%$. Commercial cultural practices for the area were followed (Calif. Strawberry Commission, 1999). The soil was tilled and beds were formed in both locations at 132-cm center-to-center spacing $(76 \mathrm{~cm}$ wide $\times 30 \mathrm{~cm}$ high). Slow release fertilizer $(27 \mathrm{~N}-10 \mathrm{P}-12 \mathrm{~K})$ was applied to the beds at the rate of $400 \mathrm{~kg} \cdot \mathrm{ha}^{-1}$. Adrip irrigation system was installed that consisted of two drip tapes (Netafim Streamline 60; Netafim, Fresno, Calif.), with emitters spaced $30 \mathrm{~cm}$ apart and an emitter flow rate of $0.87 \mathrm{~L} / \mathrm{min}$ at $70 \mathrm{KPa}$, placed $8 \mathrm{~cm}$ (in Watsonville) or $13 \mathrm{~cm}$ (in Salinas) from the bed center at a soil depth ranging from 2 to $5 \mathrm{~cm}$. This arrangement placed the drip tapes $30 \mathrm{~cm}$ from the edge of the bed in Watsonville and $25 \mathrm{~cm}$ from the edge of the bed in Salinas. Preplant treatments (Table 1) were applied to the same beds each year in late September (1999 season) or early October (2000 season), $\approx 4$ weeks before planting. The treatments were arranged in a randomized complete-block design with four replicates in Watsonville and three in Salinas. Plots were 1 bed wide $\times 10 \mathrm{~m}$ long at Watsonville and 1 bed wide $\times 33 \mathrm{~m}$ long at Salinas. At the time of fumigation, the average daily soil temperature within the raised bed ranged between 16 to $20^{\circ} \mathrm{C}$, and the average soil water content was $<85 \%$ of field capacity (soil matric potentials ranged between -7.5 and $-8.5 \mathrm{KPa}$ ).

The fumigants used in this study were commercial grade formulations. Metam sodium (Vapam HL formulation, $42 \%$ sodium $\mathrm{N}$-methyldithiocarbamate) was provided by AMVAC, Newport Beach, Calif. Chloropicrin, without and with an emulsifier (CP99\% and CP EC $95 \%$ ), was provided by Niklor Chemical Co., Long Beach, Calif. Telone C35, a mixture of 1,3-D and CP (62\% 1,3-D and 35\% CP) and an emulsified formulation of this 1,3-D and $\mathrm{CP}$ mixture (InLine, 60\% 1,3-D and 32\% CP) were provided by Dow AgroSciences, Redeck, N.C. The $67 \mathrm{MB}: 33 \mathrm{CP}$ formulation was provided by Tri-Cal., Hollister, Calif.

At both locations, $67 \mathrm{MB}: 33 \mathrm{CP}$, Telone $\mathrm{C} 35$, and $\mathrm{CP}$ were shank injected 25 to $30 \mathrm{~cm}$ deep with two chisels spaced $35 \mathrm{~cm}$ apart into soil beds that were immediately covered with green or brown high-density polyethylene mulch (0.03-mm thickness). Metam sodium, Inline, and CP EC were applied through the drip irrigation system into soil beds covered with polyethylene mulch. Chemicals were injected into the irrigation water throughout the irrigation period following procedures described by Ajwa et al. (2002). Briefly, the fumigants were injected in a closed system directly from nitrogen-pressurized cylinders and metered into irrigation water with a flow meter (Key Instruments, Trevose, Pa., McMaster Carr Supply, Los Angeles). A static mixing devise (TAH Industries, Robbinsville, N.J.) was installed at the point of injection to mix fumigants with irrigation water before distri- bution in the irrigation system. A backflow device (Amiad Filtration Systems, Oxnard, Calif.) was used to prevent contamination of the water source. InLine and metam sodium (as Vapam HL) were applied through the drip irrigation system at the maximum label rates, $393 \mathrm{~L} \cdot \mathrm{ha}^{-1}$ and $700 \mathrm{~L} \cdot \mathrm{ha}^{-1}$, in three volumes of water $\left(26,43\right.$, and $\left.61 \mathrm{~L} \cdot \mathrm{m}^{-2}\right)$ or at $60 \%$ of the maximum rates in $43 \mathrm{~L} \cdot \mathrm{m}^{-2}$. Combination treatments were applied simultaneously in 1999 and sequentially in 2000. In 1999 the combination treatments, i.e., InLine plus Vapam HL or CP plus Vapam HL, were applied simultaneously into the irrigation water. For the 2000 growing season, Vapam HL was applied as a sequential application $6 \mathrm{~d}$ after application of InLine or $\mathrm{CP}$. Before planting, at least $25 \mathrm{~mm}$ of water were applied through the drip irrigation systems to wash any residual fumigants or breakdown products from the planting zone. The Salinas irrigation water had an electrical conductivity of $0.63 \mathrm{mS} \cdot \mathrm{cm}^{-1}$ and $425 \mathrm{ppm}$ dissolved salts, and the irrigation water at Watsonville had a conductivity $0.6 \mathrm{mS} \cdot \mathrm{cm}^{-1}$ and $241 \mathrm{ppm}$ dissolved salts. Strawberry variety 'Selva' was planted 4 to 5 weeks after fumigation at a density of 49,697 plants/ha. Overhead sprinklers were used for up to four weeks to establish the strawberry transplants, and $\approx 25$ $\mathrm{mm}$ of water per week was applied. In 2000, the plastic mulch was removed after planting to allow for better estimate of weed control by the various treatments.
Weed control assessments. Fumigant efficacy on weeds was assessed by two methods: 1) biomass of the native weed population, and 2) viability of buried weed seed samples. Weeds were uprooted and shaken to remove residual soil from the roots and then fresh weights were measured to determine weed biomass. Weeds were separated by species only at Salinas in 2000. Weed samples were taken during the period 3 to 5 months after strawberry planting when their populations were at their peak.

For seed viability tests, 50 seeds of little mallow, prostrate knotweed and common purslane were placed in $8 \times 12$-cm heat-sealed nylon mesh bags (Delnet, Middletown, Del.). The little mallow seed was obtained from Valley Seed, Fresno, Calif., and the prostrate knotweed and common purslane seed were gathered from agricultural fields near Salinas, Calif. Two seed bags were buried per plot at a depth of $5 \mathrm{~cm}$ deep, one at the center and a second at the edge of the bed. Seed bags were installed 1 to $2 \mathrm{~d}$ prior to fumigation to allow the seeds to equilibrate with the soil moisture. Seed bags were retrieved $\approx 10 \mathrm{~d}$ after fumigation, and seed viability was determined using the tetrazolium assay described in Grabe (1970).

Statistical analysis. Weed biomass and seed viability data were analyzed using the SAS general linear model (GLM) procedure (SAS Institute, Cary, N.C.). Data within fumigant rates were pooled across irrigation water volumes where there were no differences be-

Table 3. California burclover and common chickweed fresh weight $\mathrm{g} \cdot \mathrm{m}^{-2}$ resulting from $\mathrm{MB}: \mathrm{CP}$ compared to CP, CP EC, Inline, Telone C35 and Vapam HL applied through the drip irrigation system or by shank injection at Salinas in 2000. The weed biomass in the Inline or CP treatments with and without sequential applications of Vapam HL was contrasted to determine if sequential applications of Vapam HL improved weed control. Weed biomass in the drip-applied Inline or shank-applied Telone C35 applications were also contrasted.

\begin{tabular}{|c|c|c|c|c|}
\hline Treatment & Rate/ha & $\begin{array}{l}\text { Application } \\
\text { method }\end{array}$ & $\begin{array}{l}\text { California } \\
\text { burclover }\end{array}$ & $\begin{array}{l}\text { Common } \\
\text { chickweed }\end{array}$ \\
\hline & Contrast & atments vs. ML & ---- & --- \\
\hline MB : CP standard & $425 \mathrm{~kg}$ & shank & 168.9 & 7.3 \\
\hline Telone C35 & $374 \mathrm{~L}$ & shank & $141.7(0.31)^{\mathrm{z}}$ & $6.3(0.98)^{z}$ \\
\hline Inline & $236 \mathrm{~L}$ & drip & $71.8(<0.01)$ & $9.8(0.97)$ \\
\hline Inline & $393 \mathrm{~L}^{y}$ & drip & $56.9(<0.01)$ & $6.9(0.99)$ \\
\hline $\mathrm{CP}$ & $317 \mathrm{~kg}$ & shank & $153.3(0.56)$ & $47.6(0.58)$ \\
\hline CP EC & $200 \mathrm{~L}$ & drip & $36.1(<0.01)$ & $15.7(0.91)$ \\
\hline Vapam HL & $420 \mathrm{~L}$ & drip & $82.2(<0.01)$ & $152.9(0.05)$ \\
\hline Vapam HL & $700 \mathrm{~L}^{\mathrm{x}}$ & drip & $81.4(<0.01)$ & $93.2(0.15)$ \\
\hline Untreated & 0 & -- & $60.5(<0.01)$ & $461.0(<0.01)$ \\
\hline
\end{tabular}

Untreated

Contrast fumigant applied alone vs. fumigant followed by (fb) Vapam $H L$

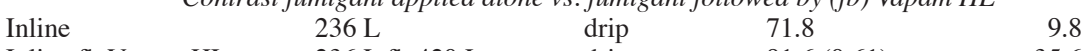

$\begin{array}{llll}\text { Inline fb Vapam HL } & 236 \mathrm{~L} \text { fb } 420 \mathrm{~L} & \text { drip } & 91.6(0.61)^{\mathrm{w}}\end{array}$

Inline $393 \mathrm{~L}^{\mathrm{y}}$

Inline fb Vapam HL

CPEC

$393 \mathrm{~L} \mathrm{fb} 700 \mathrm{~L} \quad$ drip $\quad 54.8(0.93)$

6.9

$2.2(0.94)$

CP EC fb Vapam HL

$200 \mathrm{~L}$

31.6

15.7

$12.0(0.96)$

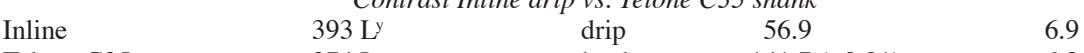

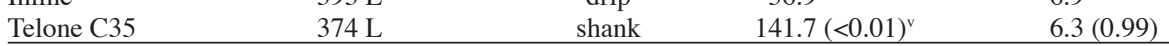

${ }^{2} P$ value of single degree of freedom contrasts comparing weed biomass weights with the MB:CP standard.

${ }^{y}$ Average weed biomass of Inline at $393 \mathrm{~L} \cdot \mathrm{ha}^{-1}$ applied by drip irrigation in three application volumes: 26 , 43 , and $61 \mathrm{~L} \cdot \mathrm{m}^{-2}$

${ }^{x}$ Average weed biomass of Vapam HL at $700 \mathrm{~L} \cdot \mathrm{ha}^{-1}$ applied by drip irrigation in three application volumes: 26,43 , and $61 \mathrm{~L} \cdot \mathrm{m}^{-2}$

${ }^{w} P$ value of single $\mathrm{df}$ contrasts comparing the weed biomass of Inline or CP EC treatments applied with a sequential application of Vapam HL were compared to Inline or CP EC applied without Vapam HL.

${ }^{v} P$ value of single $\mathrm{df}$ contrasts comparing the weed biomass from the Inline drip-applied treatment to the Telone C35 shank-applied treatment. 
Table 4. Efficacy of CP, CP EC, Inline, Telone C35 and Vapam HL on prostrate knotweed seed viability compared to MB : CP at Salinas in 2000. The data are percentage viable seed buried in the center and edge of a 1-m bed. The seed viability in the Inline or CP EC treatments with and without sequential applications of Vapam HL were compared to determine if sequential applications of Vapam HL improved weed control. Seed viability in the drip applications of Inline and shank applications of Telone C35 were also contrasted. The center vs. edge $P$ value indicates whether treatment effect on seed viability at the center vs. edge of the bed differed.

\begin{tabular}{|c|c|c|c|c|c|}
\hline \multirow[b]{2}{*}{ Treatment } & \multirow[b]{2}{*}{ Rate/ha } & \multirow{2}{*}{$\begin{array}{l}\text { Application } \\
\text { method }\end{array}$} & \multicolumn{3}{|c|}{ Prostrate knotweed } \\
\hline & & & Center & Edge & Center vs. edge \\
\hline \multicolumn{4}{|c|}{ Contrast single treatments vs. $\bar{M} \bar{B}: \bar{C} P$ standard ---} & & \\
\hline MB : CP standard & $425 \mathrm{~kg}$ & shank & 14.18 & 24.07 & 0.69 \\
\hline Telone C35 & $374 \mathrm{~L}$ & shank & $1.67(0.33)^{2}$ & $29.82(0.86)$ & 0.16 \\
\hline Inline & $236 \mathrm{~L}$ & drip & $0.50(0.24)$ & $11.54(0.64)$ & 0.39 \\
\hline Inline & $393 \mathrm{~L}^{y}$ & drip & $1.32(0.22)$ & $7.16(0.41)$ & 0.40 \\
\hline $\mathrm{CP}$ & $317 \mathrm{~kg}$ & shank & $86.40(<0.01)$ & $92.69(0.04)$ & 0.79 \\
\hline CP EC & $200 \mathrm{~L}$ & drip & $27.95(0.52)$ & $54.04(0.39)$ & 0.40 \\
\hline Vapam HL & $420 \mathrm{~L}$ & drip & $46.66(0.17)$ & $96.90(0.02)$ & 0.04 \\
\hline Vapam HL & $700 \mathrm{~L}^{\mathrm{x}}$ & drip & $72.42(<0.01)$ & $96.61(<0.01)$ & 0.04 \\
\hline Untreated & 0 & --- & $95.50(<0.01)$ & $99.50(<0.01)$ & 0.65 \\
\hline \multicolumn{6}{|c|}{ Contrast fumigant applied alone vs. fumigant followed by (fb) Vapam $H L$} \\
\hline Inline & $236 \mathrm{~L}$ & drip & 0.50 & 11.54 & --- \\
\hline Inline fb Vapam HL & $236 \mathrm{~L} \mathrm{fb} 420 \mathrm{~L}$ & drip & $0.50(1.00)^{\mathrm{w}}$ & $52.53(0.20)$ & 0.02 \\
\hline Inline & $393 \mathrm{~L}^{y}$ & drip & 1.32 & 7.16 & --- \\
\hline Inline fb Vapam HL & $393 \mathrm{~L} \mathrm{fb} 700 \mathrm{~L}$ & drip & $0.50(0.83)$ & $0.65(0.52)$ & 0.98 \\
\hline CP EC & $200 \mathrm{~L}$ & drip & 27.95 & 54.04 & --- \\
\hline CP EC fb Vapam HL & $200 \mathrm{~L} \mathrm{fb} 420 \mathrm{~L}$ & drip & $0.50(0.08)$ & $60.71(0.85)$ & 0.02 \\
\hline \multicolumn{6}{|c|}{ Contrast Inline drip vs. Telone C35 shank } \\
\hline Inline & $393 \mathrm{~L}^{y}$ & drip & 1.32 & 7.16 & --- \\
\hline Telone C35 & $374 \mathrm{~L}$ & shank & $1.07(0.95)^{\mathrm{v}}$ & $29.82(0.30)$ & --- \\
\hline
\end{tabular}

${ }^{\mathrm{Z} P}$ value of single degree of freedom contrasts comparing weed biomass weights with the MB : CP standard.

${ }^{y}$ Average weed biomass of Inline at $393 \mathrm{~L} \cdot \mathrm{ha}^{-1}$ applied by drip irrigation in three application volumes: 26 , 43 and $61 \mathrm{~L} \cdot \mathrm{m}^{-2}$.

${ }^{x}$ Average weed biomass of Vapam HL at $700 \mathrm{~L} \cdot \mathrm{ha}^{-1}$ applied by drip irrigation in three application volumes: 26, 43 and $61 \mathrm{~L} \cdot \mathrm{m}^{-2}$

${ }^{\text {w }} P$ value of single df contrasts comparing the weed biomass of Inline or CP treatments applied with a sequential application of Vapam HL were compared to Inline or CP applied without Vapam HL.

${ }^{v} P$ value of single $\mathrm{df}$ contrasts comparing the weed biomass from the Inline drip-applied treatment to the Telone C35shank-applied treatment.

tween irrigation treatments. Single degree-offreedom contrasts were used to make specific comparisons between treatments. The standard MB : CP was compared to alternative chemical treatments. The effect of a fumigant applied singly was compared to the effect of the same fumigants applied in combination with Vapam HL. The efficacy of drip-applied InLine was compared to shank-applied Telone C35. To determine if there were spatial differences in weed control across the planting beds, the viability of weed seed buried in the center of the bed was compared to that of seed buried at the edge of the bed. Statistical analyses were performed on the weed fresh weight data without transformation. Weed seed viability data were arcsine transformed before analysis to normalize variances. Means were converted to original units after analysis.

\section{Results}

Fumigant efficacy on native weeds. Statistical analysis indicated that the weed control and weed seed viability values resulting from drip-applied InLine at $393 \mathrm{~L} \cdot \mathrm{ha}^{-1}$ applied in 26,43 , and $61 \mathrm{~L} \cdot \mathrm{m}^{-2}$ of water were not significantly different, so these data were pooled. Similarly, the data from the Vapam HL 700 $\mathrm{L} \cdot \mathrm{ha}^{-1} 26,43$, and $61 \mathrm{~L} \cdot \mathrm{m}^{-2}$ treatments were also pooled. InLine, $\mathrm{CPEC}$ or Telone $\mathrm{C} 35$ alone did not significantly differ from $\mathrm{MB}: \mathrm{CP}$ in biomass than shank-applied Telone C35. The control of common chickweed provided by InLine, Telone C35, CP EC, and CP treatments were not significantly different $(P<$ 0.05) than MB : CP (Table 3). Vapam HL alone at $420 \mathrm{~L} \cdot \mathrm{ha}^{-1}$ resulted in significantly greater common chickweed biomass than MB : CP. Applications of Vapam HL after InLine or CP EC did not improve the common chickweed control provided by each chemical applied singly. Also, InLine at $393 \mathrm{~L} \cdot \mathrm{ha}^{-1}$ and Telone $\mathrm{C} 35$ at $374 \mathrm{~L} \cdot \mathrm{ha}^{-1}$ did not differ significantly in common chickweed control.

Fumigant efficacyon weed seed. There were significant differences in fumigant efficacy on the weed seed in the center of the bed compared to the edge of the bed. The single Vapam HL applications, or combination treatments of InLine at $236 \mathrm{~L} \cdot \mathrm{ha}^{-1}$ or CP EC followed by Vapam HL provided significantly better control of prostrate knotweed seed in the bed center than at the edge of the bed (Table 4).

The effect of InLine, Telone C35 or CP EC on prostrate knotweed seed viability did not differ significantly from the MB : CP standard (Table 4). Shank-applied CP provided significantly less control of prostrate knotweed seed than MB : CP, regardless of seed location in the bed. Vapam HL at $420 \mathrm{~L} \cdot \mathrm{ha}^{-1}$ provided significantly less control of prostrate knotweed seed on the bed edge than MB : CP, and Vapam $\mathrm{HL}$ at $700 \mathrm{~L} \cdot \mathrm{ha}^{-1}$ provided significantly less control of prostrate knotweed seed in either the bed center or edge compared to $\mathrm{MB}: \mathrm{CP}$. The prostrate knotweed control provided by InLine or CP EC was not improved by application of Vapam HL. InLine and Telone C35 applied at maximum labeled rate did not significantly differ in efficacy on prostrate knotweed seed. At Salinas in 2000, all of the fumigants reduced the viability of common purslane seed to near zero, and none of the fumigants (including MB : $\mathrm{CP}$ ) reduced little mallow seed viability compared to the untreated (data not shown).

At Watsonville, all of the single fumigant treatments provided control of prostrate knotweed seed buried at the bed center equivalent to MB : CP(Table 5). However, for seed buried at the edge of the bed, all but Telone $\mathrm{C} 35$ provided significantly less control of prostrate knotweed seed than MB : CP. Application of Vapam HL in combination with InLine or CP EC did not improve control of prostrate knotweed seed. Furthermore, the combination treatment of InLine at $236 \mathrm{~L} \cdot \mathrm{ha}^{-1}$ followed by Vapam HL at $420 \mathrm{~L} \cdot \mathrm{ha}^{-1}$ had significantly less activity on prostrate knotweed seed than InLine applied singly at $236 \mathrm{~L} \cdot \mathrm{ha}^{-1}$. Applications of Vapam HL after CP EC provided significantly better prostrate knotweed seed control in the center of the bed than at the edge. InLine and Telone C35 did not differ in controlling prostrate knotweed on the center or edge of the beds.

Treatments that provided significantly better control of little mallow seed in the bed center than MB : CP were InLine at 393 $\mathrm{L} \cdot \mathrm{ha}-1$ and CPEC at $130 \mathrm{~L} \cdot \mathrm{ha}^{-1}$ and Vapam HL alone at 420 or $700 \mathrm{~L} \cdot \mathrm{ha}^{-1}$ (Table 6). However, the percentage of viable seed was too high in these treatments to be considered effective control. At the edge of the bed, none of the 
Table 5. Efficacy of CP, CP EC, Inline, Telone C35 and Vapam HL on prostrate knotweed seed viability compared to MB : CP at Watsonville in 2000. The data are percentage viable seed buried in the center and edge of a 1-m bed. The seed viability in the Inline or CP treatments with and without sequential applications of Vapam HL were compared to determine if sequential applications of Vapam HLimproved weed control. Seed viability in the drip applications of Inline and shank applications of Telone C35 were also contrasted. The center vs. edge $P$-value indicates whether treatment effect on seed viability at the center vs. edge of the bed differed.

\begin{tabular}{|c|c|c|c|c|c|}
\hline \multirow[b]{2}{*}{ Treatment } & \multirow[b]{2}{*}{ Rate/ha } & \multirow{2}{*}{$\begin{array}{c}\text { Application } \\
\text { method }\end{array}$} & \multicolumn{3}{|c|}{ Prostrate knotweed } \\
\hline & & & Center & Edge & Center vs. edge \\
\hline & & & -- viab & $(\%)$ & $P$ value \\
\hline \multicolumn{6}{|c|}{ Contrast single treatments vs. $M B: C P$ standard } \\
\hline MB : CP standard & $425 \mathrm{~kg}$ & shank & 0.13 & 1.77 & 0.73 \\
\hline Telone C35 & $374 \mathrm{~L}$ & shank & $0.25(0.92)^{\mathrm{z}}$ & $26.82(0.26)$ & 0.08 \\
\hline Inline & $236 \mathrm{~L}$ & drip & $0.06(0.95)$ & $88.63(<0.01)$ & $<0.01$ \\
\hline Inline & $393 \mathrm{~L}^{\mathrm{y}}$ & drip & $0.07(0.95)$ & $49.38(0.04)$ & $<0.01$ \\
\hline CP EC & $130 \mathrm{~L}$ & drip & $1.83(0.52)$ & $89.27(0.03)$ & $<0.01$ \\
\hline Vapam HL & $420 \mathrm{~L}$ & drip & $5.45(0.20)$ & $91.70(<0.01)$ & $<0.01$ \\
\hline Vapam HL & $700 \mathrm{~L}^{\mathrm{x}}$ & drip & $3.17(0.29)$ & $90.48(<0.01)$ & $<0.01$ \\
\hline Untreated & 0 & --- & $98.3(<0.01)$ & $79.80(<0.01)$ & 0.28 \\
\hline \multicolumn{6}{|c|}{ Contrast fumigant applied alone vs. fumigant followed by $(\mathrm{fb})$ Vapam $\mathrm{HL}$} \\
\hline Inline & $236 \mathrm{~L}$ & drip & 0.06 & 88.63 & --- \\
\hline Inline fb Vapam HL & $236 \mathrm{~L} \mathrm{fb} 420 \mathrm{~L}$ & drip & $18.46(<0.01)^{\mathrm{w}}$ & $23.91(.07)$ & 0.81 \\
\hline CP EC & $130 \mathrm{~L}$ & drip & 1.83 & 89.27 & --- \\
\hline CP EC fb Vapam HL & $130 \mathrm{~L} \mathrm{fb} 420 \mathrm{~L}$ & drip & $0.06(0.48)$ & $64.42(0.25)$ & $<0.01$ \\
\hline \multicolumn{6}{|c|}{ Contrast Inline drip vs. Telone C35 shank } \\
\hline Inline & $393 \mathrm{~L}^{\mathrm{y}}$ & drip & 0.07 & 49.38 & --- \\
\hline Telone C35 & $374 \mathrm{~L}$ & shank & $0.25(0.85)^{\mathrm{v}}$ & $26.82(0.43)$ & 0.08 \\
\hline
\end{tabular}

${ }^{\mathrm{z} P}$ value of single degree of freedom contrasts comparing weed biomass weights with the MB : CP standard.

${ }^{y}$ Average weed biomass of Inline at $393 \mathrm{~L} \cdot \mathrm{ha}^{-1}$ applied by drip irrigation in three application volumes: 26 , 43 and $61 \mathrm{~L} \cdot \mathrm{m}^{2}$.

${ }^{\mathrm{x}}$ Average weed biomass of Vapam HL at $700 \mathrm{~L} \mathrm{ha}^{-1}$ applied by drip irrigation in three application volumes: 26, 43 and $61 \mathrm{~L} \cdot \mathrm{m}^{2}$

${ }^{\text {w}} P$ value of single df contrasts comparing the weed biomass of Inline or CP treatments applied with a sequential application of Vapam HL were compared to Inline or CP applied without Vapam HL.

${ }^{v} P$ value of single df contrasts comparing the weed biomass from the Inline drip-applied treatment to the Telone C35shank-applied treatment.

treatments, had a significant effect on little mallow seed viability. The application of Vapam HL after InLine or CP EC did not improve the control of little mallow seed. At the bed center, InLine provided significantly better control of little mallow seed than Telone C35.

\section{Discussion}

Results from our studies suggest that the following treatments can provide weed control equivalent to shank injection of $\mathrm{MB}$ : CP: 1) drip fumigation with InLine at 236 or $393 \mathrm{~L} \cdot \mathrm{ha}^{-1}$; 2) CP EC at $>130 \mathrm{~L} \cdot \mathrm{ha}^{-1}$; and 3) shank injection of Telone C35 at $374 \mathrm{~L} \cdot \mathrm{ha}^{-1}$. At times, drip fumigation with InLine provided better weed control than shank injection with the same rates of Telone $\mathrm{C} 35$ or $\mathrm{CP}$ (Tables 2, 3, and 6). This may be due to increased retention of the fumigant in the soil where drip application was used (Ajwa and Trout, 2000). The advantage of the shank application compared to the drip application, may be in weed control on the edge of the bed. The shank-applied materials were injected with shanks spaced $35 \mathrm{~cm}$ apart (20 $\mathrm{cm}$ from the edge of the bed) that resulted in fairly uniform concentrations of the fumigant across the bed (H. Ajwa, unpublished results). With drip fumigation, the distribution of chemicals was controlled by initial water distribution. Fumigants applied through the drip irrigation system must move with water so that the fumigant can be delivered to the target zone where the fumigant contacts not provide sufficient control of weed seed on the edges of the beds compared to MB : $\mathrm{CP}$ (Tables 4 and 5). This could be due to the fast generation and dissipation of MITC during and immediately after Vapam HL application. Inadequate lateral movement of the application water may have contributed to the poor weed control at the edge of the bed. Other studies have reported that Vapam HL is generally more effective when applied in irrigation water (chemigation) than by shank injection (Baines et al., 1957; McGovern et al. 1998; Noling and Becker, 1994; Roberts et al., 1988). Our results indicate that the efficacy of MITC generated from Vapam HLduring and after drip fumigation may differ from other chemigation practices (such as sprinkler application), and that drip irrigation systems should be designed for optimum lateral soil distribution of Vapam HL rather than for irrigation purposes only.

When CP EC and Vapam HL were applied simultaneously for the 1999 growing season, the weed control efficacy was diminished (Table 2). This may be due to rapid degradation/hydrolysis of CP and Vapam HL in the irrigation water such that fumigant efficacy was reduced (Trout and Ajwa, 1999). Because of this chemical incompatibility, Vapam HL treatments in 2000 were applied as sequential treatments $6 \mathrm{~d}$ after the application of InLine or CP EC. However, the small contribution of Vapam HL to weed control after drip fumigation with InLine or CP EC may indicate that these fumigants have greater activity in the water phase against weeds than Vapam HL. The results presented here suggest that application of Vapam HL after drip fumigation with InLine or CP EC is not needed. However, in other research we have found that weed densities and hand weeding times were reduced when Vapam HL was applied after shank injection of CP (Fennimore et al., 2001). Also, the combination treatments resulted in excellent control of soilborne pathogens and produced strawberry yields equivalent to MB : CP treatments (Ajwa and Trout, 2000). Further research will be necessary to determine if the economic benefits of sequential applications of Vapam HL are justified in commercial fields.

The amount of California burclover in the $\mathrm{MB}: \mathrm{CP}$ treatment was greater than that found in the untreated check. Two possible explanations for this result are: 1) that California burclover in the MB : CP plots were not subjected to the competition from other easily controlled weeds such as common chickweed that were abundant in the untreated plots, thus the California burclover plants grew larger in the MB : CP plots, and/or 2) that the MB : CP stimulated California burclover seed germination and thus there were more California burclover plants in the MB : CP plots. While there is no direct evidence of $\mathrm{MB}: \mathrm{CP}$ stimulation of seed germination, it has been demonstrated that low doses of metam sodium stimulate the germination of dormant large crabgrass seed (Teasdale and Taylorson, 1986). It is possible that MB : CP stimulates the germination of dormant California burclover seed. Biomass of California burclover from the drip-applied 1,3$\mathrm{D}: \mathrm{CP}$ or $\mathrm{CP}$ treatments did not differ from the 
Table 6. Efficacy of CP, CP EC, Inline, Telone C35, and Vapam HL on little mallow seed viability compared to MB : CP at Watsonville in 2000. The data are percentage viable seed buried in the center and edge of a 1-m bed. The seed viability in the 1,3-D:CP or CP treatments with and without sequential applications of Vapam HL were contrasted to determine if sequential applications of Vapam HL improved weed control. Seed viability in the drip applications of Inline and shank applications of Telone C35 were also contrasted. The center vs. edge $P$ value indicates whether treatment effect on seed viability at the center vs. edge of the bed differed.

\begin{tabular}{|c|c|c|c|c|c|}
\hline \multirow[b]{2}{*}{ Treatment } & \multirow[b]{2}{*}{ Rate/ha } & \multirow{2}{*}{$\begin{array}{l}\text { Application } \\
\text { method }\end{array}$} & \multicolumn{3}{|c|}{ Little mallow } \\
\hline & & & Center & Edge & Center vs. edge \\
\hline \multicolumn{4}{|c|}{ Contrast single treatments vs. $\bar{M} \bar{B}: \bar{C} P$ standard } & & \\
\hline MB : CP standard & $425 \mathrm{~kg}$ & shank & 88.66 & 83.50 & 0.20 \\
\hline Telone C35 & $374 \mathrm{~L}$ & shank & $86.84(0.59)^{z}$ & $79.65(0.39)$ & 0.09 \\
\hline Inline & $236 \mathrm{~L}$ & drip & $85.71(0.39)$ & $85.11(0.76)$ & 0.88 \\
\hline Inline & $393 \mathrm{~L}^{\mathrm{y}}$ & drip & $76.90(<0.01)$ & $78.71(0.20)$ & 0.30 \\
\hline CP EC & $130 \mathrm{~L}$ & drip & $80.65(0.03)$ & $84.69(0.39)$ & 0.34 \\
\hline Vapam HL & $420 \mathrm{~L}$ & drip & $80.71(0.03)$ & $83.87(0.50)$ & 0.46 \\
\hline Vapam HL & $700 \mathrm{~L}^{\mathrm{x}}$ & drip & $82.02(0.03)$ & $79.22(0.22)$ & 0.37 \\
\hline Untreated & 0 & --- & $82.80(0.12)$ & $80.00(0.46)$ & 0.51 \\
\hline \multicolumn{6}{|c|}{ Contrast fumigant applied alone vs. fumigant followed by $(f b)$ Vapam $H L$} \\
\hline Inline & 285.6 & drip & 85.71 & 85.11 & --- \\
\hline Inline fb Vapam HL & $285.6 \mathrm{fb} 212$ & drip & $82.58(0.40)^{\mathrm{w}}$ & $78.39(0.34)$ & 0.35 \\
\hline CP EC & $130 \mathrm{~L}$ & drip & 80.65 & 84.69 & --- \\
\hline CP EC fb Vapam HL & $130 \mathrm{~L} \mathrm{fb} 420 \mathrm{I}$ & L drip & $80.02(0.88)$ & $75.59(0.11)$ & 0.34 \\
\hline \multicolumn{6}{|c|}{ Contrast Inline drip vs. Telone C35 shank } \\
\hline Inline & $393 \mathrm{~L}^{\mathrm{y}}$ & drip & 76.90 & 78.71 & --- \\
\hline Telone C35 & $374 \mathrm{~L}$ & shank & $86.84(<0.01)^{\mathrm{v}}$ & $79.65(0.82)$ & --- \\
\hline
\end{tabular}

${ }^{\mathrm{z}} \mathrm{P}$ value of single degree of freedom contrasts comparing weed biomass weights with the MB : CP standard.

${ }^{y}$ Average weed biomass of Inline at $393 \mathrm{~L} \cdot \mathrm{ha}^{-1}$ applied by drip irrigation in three application volumes: 26 , 4,3 and $61 \mathrm{~L} \cdot \mathrm{m}^{-2}$.

${ }^{x}$ Average weed biomass of Vapam HL at $700 \mathrm{~L} \cdot \mathrm{ha}^{-1}$ applied by drip irrigation in three application volumes: 26, 43, and $61 \mathrm{~L} \cdot \mathrm{m}^{-2}$.

${ }^{\text {w }} P$ value of single df contrasts comparing the weed biomass of Inline or CP EC treatments applied with a sequential application of Vapam HL were compared to Inline or CP EC applied without Vapam HL.

${ }^{v} P$ value of single df contrasts comparing the weed biomass from the Inline drip-applied treatment to the Telone C35 shank-applied treatment.

untreated control, although weed competition was reduced, suggesting that these fumigants do not stimulate weed seed, as does MB : CP. Another possibility is that InLine or CP EC are more active on California burclover seed than MB : CP, and thus kill more weed seed. Further research is needed before a definite conclusion can be made.

In conclusion, drip fumigation and shank injection with $\mathrm{CP}$ or a mixture of $1,3-\mathrm{D}$ and $\mathrm{CP}$ (InLine and Telone C35) were highly active on the same weed species that $\mathrm{MB}: \mathrm{CP}$ readily controls such as common chickweed. These fumigants were not effective on hardto-control weeds such as little mallow, a weed that is also difficult to manage with MB : CP. Drip fumigation with InLine or CP EC alone may provide better control of California burclover than MB : CP. Drip fumigation with InLine may provide better weed control than shank injection of Telone C35 at equivalent rates. Under the conditions in this research, the application of Vapam HL $6 \mathrm{~d}$ after drip fumigation with InLine or CP EC was not justified for weed control. Estimates suggest that costs for most of these alternative fumigant treatments will be less than $\mathrm{MB}: \mathrm{CP}$ (Table 1). For example, the cost of InLine fb Vapam HL at $236 \mathrm{fb} 420 \mathrm{~L} \cdot \mathrm{ha}^{-1}$ was estimated at $\$ 1,802$ (Table 1). Further research is needed to evaluate whether the use of Vapam HLfollowing InLine or CP EC is a justifiable expense in terms of reduced hand weeding time as well as crop yield. Another line of research that should be followed is the order of fumigant application.
For example, drip application of Vapam HL followed by InLine or CPEC application, may allow for reduced fumigant rates or improved efficacy. Teasdale and Taylorson (1986) found that low rates of metam sodium stimulated the germination of dormant large crabgrass seed. If low doses of metam sodium can be used to stimulate germination of dormant weed seed, then a sequential application of a fumigant such as drip-applied CP can be used to kill the germinating weed seed. This strategy may result in improved weed control.

\section{Literature Cited}

Agamalian, H.S., C.L. Elmore, and B.B. Fischer. 1994. Weeds, p. 99-113. In: M.L. Flint (ed.). Integrated pest management for strawberries. Univ. of California IPM publ. no. 3351. Oakland, Calif.

Ajwa, H. and T. Trout. 2000. Strawberry growth and yield with three years of drip fumigation. Annu. Intl. Res. Conf. on Methyl Bromide Alternatives and Emissions Reductions. Orlando, Fla. Abstr. 25

Ajwa, H., T. Trout, S.D. Nelson, and M. Schutter 2001. Drip fumigation: Water and fumigant distribution in soil. Annu. Intl. Res. Conf. on Methyl Bromide Alternatives and Emissions Reductions. San Diego. Abstr. 50.

Ajwa,H.A., T. Trout, J.Mueller, S. Wilhelm, S.D. Nelson, R. Soppe, and D. Shatley. 2002. Application of alternative fumigants through drip irrigation systems. Phytopathology 92:1349-55.

Baines, R.C., R.H. Small, T.A. DeWolfe., J.P. Martin, and L.H. Stolzy. 1957. Control of the citrus nematode and Phytophthora spp. by Vapam. Plant Dis. Rpt. 41:405-414.
California Strawberry Commission. 1999. Crop profile of strawberries in California. National Pesticide Assessment Program. Available online at: http://pestdata.ncsu.edu/cropprofiles/docs/ castrawberries.html

Carter, C. 2001. Methyl bromide phaseout becomes reality. Calif. Agr. 55(3):2.

Duniway, J.M., J.J. Hao, D.M. Dopkins, H. Ajwa, and G.T. Browne. 2001. Chemical, cultural and biological alternatives to methyl bromide for strawberry. Annu. Intl. Res. Conf. on Methyl Bromide Alternatives and Emissions Reductions. San Diego. Abstr. 41.

Egley, G.H. 1986. Stimulation of weed seed germination in soil. Rev. of Weed Sci. 2:67-89.

EXTOXNET - CP. 2001. Pesticide information profile-Chloropicrin. Extension Toxicology Network. Available online at: http:pmep.cce. cornell.edu/profiles/extonet/carbaryldicrotophos/chloropicrin-ext.html.

EXTOXNET - MB. 2001. Pesticide information profile-Methyl bromide. Extension Toxicology Network. Available online at: http:pmep. cce.cornell.edu/profiles/extonet/haloxyfopmethylparathion/methyl-bromide-ext.html.

Fennimore, S.A., M.J. Haar, and H. Ajwa. 2001. Alternative fumigant efficacy on weeds in strawberry nursery and fruiting fields. Annu. Intl. Res. Conf. of Methyl Bromide Alternatives and Emissions Reductions. Abstr. 39.

Grabe, D.F. 1970. Tetrazolium testing handbook for agricultural seeds. Contribution No. 29 to the Handbook on seed testing. Assn. of Official Seed Analysts.

Johnson, A.W. and J. Feldmesser. 1987. Nematicides-A historical review, p. 448-454. In: J.A. Veech and D.W. Dickson (eds.). Vistas on nematology. Soc. of Nematologists, Hyattsville, Md.

Johnson, A.W., S.M. McCarter, C.A. Jaworski, and R.E. Williamson. 1979. Chemical control of nematodes and soilborne plant-pathogenic fungi on cabbage transplants. J. Nematol. 11: 138-144.

Klonsky, K.M. and R.L. De Moura. 2001. Sample costs to produce fresh market strawberries. Univ. of California Coop. Ext. Available online at: http: //coststudies.ucdavis.edu.

Lakes Environmental Software. 2000. 1,3-dichloropropene fact sheet. Lakes Environmental Software. Available online at: http://lakes-environmental.com.toxic/1_3dichloropropene.html.

Lange, A.H. 1985. Soft fruits, p. 325-355. In: E.A. Kurtz (ed.). Principals of weed control in California. Thompson Publication, Fresno, Calif.

Locascio, S.J., J.P. Gilreath, D.W. Dickson, T.A. Kucharek, J.P. Jones, and J.W. Noling. 1997. Fumigant alternatives to methyl bromide for polyethylene-mulched tomato. HortScience 32:1208-1211.

Makowski, R. and M.D. Morrison. 1989. The biology of Canadian weeds. 91. Malva pusilla Sm. Can. J. Plant Sci. 69:861-879.

McCarter, S.M., C.A. Jaworski, and A.W. Johnson. 1976. Soil fumigation effects on early blight of tomato transplants. Phytopathology $66,1122-1124$.

McGovern, R.J., C.S. Vavrina, J.W. Noling, L.A. Datnoff, and H.D. Yonce. 1998. Evaluation of application methods of metam sodium for management of Fusarium crown and root rot in tomato in southwest Florida. Plant Dis. 82: 919-923.

Noling, J.W. and J.O. Becker. 1994. The challenge of research and extension to define and implement alternative to methyl bromide. Suppl. J. Nematol. 26:573-586.

Pieczarka, S.J. and G.F. Warren. 1959. Screening 
procedure for determining the activity of chemicals against imbibed dormant seeds. Weeds 7 : 133-140.

Pieczarka, S.J. and G.F. Warren. 1960. The influence of concentration of fumigant and time of exposure on killing of dormant imbibed seeds. Weeds 8 : 612-615.

Porqueddu, C., A. Loi, and P.S. Cocks. 1996. Hardseededness and pattern of hard seed breakdown in Sardinian populations of Medicago polymorpha under field conditions. J. Agr. Sci. 126:161-168.
Roberts, P.A., A.C. Magyarosy, W.C. Matthews, and D.M. May. 1988. Effects of Metam-sodium applied by drip irrigation on Root-knot nematodes Pythium ultimum and Fusarium sp. in soil and on carrot and tomato roots. Plant Dis. 72:213-217.

Teasdale, J.R. and R.B. Taylorson. 1986. Weed seed response to methyl isothiocyanate and metham. Weed Sci. 34:520-524.

Trout, T. and H. Ajwa. 1999. Strawberry response to fumigants applied by drip irrigation systems. Annu. Intl. Res. Conf. on Methyl Bromide Alter- natives and Emissions Reductions. San Diego. Abstr. 10.

U.S. Department of Agriculture. 2000. Economic implications of the methyl bromide phaseout Agr. Info. Bul. No. 756, Washington, D.C.

Wilhelm, S. 1999. The California strawberry industry and soil fumigation. A review. Published by the California Strawberry Commission, Watsonville, Calif.

Wilhelm, S. and A.O. Paulus. 1980. How soil fumigation benefits the California strawberry industry. Plant Dis. 64:264-270. 